\title{
Endodontic images as a forensic identification: A literature review
}

\author{
Imagens endodônticas como identificação forense: Uma revisão da literatura \\ Imágenes endodónticas como identificación forense: Revisión de la literatura
}

Received: 06/09/2021 | Reviewed: 06/19/2021 | Accept: 06/24/2021 | Published: 07/10/2021

\author{
Júlia Guerra de Andrade \\ ORCID: https://orcid.org/0000-0001-8167-2535 \\ Universidade Estadual Paulista, Brasil \\ E-mail: julia.guerra@unesp.br \\ Gabriel Andrade Nunes Carrijo \\ ORCID: https://orcid.org/0000-0001-5710-0545 \\ Universidade Estadual Paulista, Brasil \\ E-mail: gabrielkarrijo@gmail.com \\ Caroline Loureiro \\ ORCID: https://orcid.org/0000-0002-9035-2960 \\ Universidade Estadual Paulista, Brasil \\ E-mail: caroline.loureiro@unesp.br \\ Ana Paula Fernandes Ribeiro \\ ORCID: https://orcid.org/0000-0001-5313-5003 \\ Universidade Estadual Paulista, Brasil \\ E-mail: apf.ribeiro@unesp.br \\ Gladiston William Lobo Rodrigues \\ ORCID: https://orcid.org/0000-0002-1286-3984 \\ Universidade Estadual Paulista, Brasil \\ E-mail: gladiston.william@unesp.br \\ Rogério de Castilho Jacinto \\ ORCID: https://orcid.org/0000-0002-2362-8920 \\ Universidade Estadual Paulista, Brasil \\ E-mail: rogerio.castilho@unesp.br
}

\begin{abstract}
Several radiographs are taken during endodontic treatment, thus providing a large number of images with individual characteristics that can be used for forensic identification of an individual. This study aimed to review the literature related to the use of endodontic radiographs in the identification of cadavers. A bibliographic search was carried out in the following databases: PubMed, Scielo, Periódicos Capes, and Web of Science. The keywords used were: forensic dentistry, endodontics, dental radiography, forensic identification. In total, 24 articles related to radiography in the identification of cadavers were found. Among them, 8 studies were selected for including endodontic radiographs for this purpose, comprising different types of studies: case reports of forensic identification through endodontic radiography (4); "in vitro" studies on the influence of high temperatures on endodontic materials and their radiographic images (2); a literature review on how radiographs can be used for identification (1); a comparative study between antemortem and post-mortem endodontic radiographic images (1). Overall, the present study showed that endodontic radiographs have a significant amount of information that can be used to identify a cadaver. Therefore, it is important to perform and store radiographs properly and for long periods. Literature related to the subject is still scarce and further studies are needed.
\end{abstract}

Keywords: Forensic dentistry; Endodontics; Dental radiography; Forensic Anthropology.

\section{Resumo}

Diversas radiografias são realizadas durante o tratamento endodôntico, proporcionando assim um grande número de imagens com características individuais que podem ser utilizadas para a identificação forense de um indivíduo. Este estudo teve como objetivo revisar a literatura relacionada ao uso de radiografias endodônticas na identificação de cadáveres. Para tanto, foi realizada uma busca bibliográfica nas seguintes bases de dados: PubMed, Scielo, Periódicos Capes e Web of Science. As palavras-chave utilizadas foram odontologia forense, endodontia, radiografia dentária, identificação forense. No total, foram encontrados 24 artigos relacionados à radiografia na identificação de cadáveres. Dentre eles, 8 estudos foram selecionados por incluir radiografias endodônticas para esse fim, compreendendo diferentes tipos de estudos: relatos de caso de identificação forense por meio de radiografia endodôntica (4); estudos "in vitro" sobre a influência das altas temperaturas nos materiais endodônticos e suas imagens radiográficas (2); revisão da literatura sobre como as radiografias podem ser utilizadas para identificação (1); estudo comparativo entre imagens radiográficas endodônticas antemortem e post-mortem (1). De maneira geral, o presente estudo mostrou que 
o uso de radiografias endodônticas possui uma quantidade significativa de informações que podem ser utilizadas para identificar um cadáver. Portanto, é importante realizar e armazenar as radiografias de maneira adequada e por longos períodos. A literatura relacionada ao assunto ainda é escassa e novos estudos são necessários.

Palavras-chave: Odontologia legal; Endodontia; Radiografia dentária; Antropologia Forense.

\section{Resumen}

Se toman varias radiografías durante el tratamiento de endodoncia, lo que proporciona una gran cantidad de imágenes con características individuales que se pueden utilizar para la identificación forense de un individuo. Este estudio tuvo como objetivo revisar la literatura relacionada con el uso de radiografías endodónticas en la identificación de cadáveres. Por ello, se realizó una búsqueda bibliográfica en las siguientes bases de datos: PubMed, Scielo, Capes Periodicals y Web of Science. Las palabras clave utilizadas fueron odontología forense, endodoncia, radiografía dental, identificación forense. En total, se encontraron 24 artículos relacionados con la radiografía en la identificación de cadáveres. Entre ellos, se seleccionaron 8 estudios para incluir radiografías de endodoncia para este propósito, que comprenden diferentes tipos de estudios: reporte de caso de identificación forense mediante radiografía de endodoncia (4); Estudios "in vitro" sobre la influencia de las altas temperaturas en los materiales endodónticos y sus imágenes radiográficas (2); revisión de la literatura sobre cómo se pueden utilizar las radiografías para la identificación (1); estudio comparativo entre imágenes radiográficas endodónticas antemortem y post-mortem (1). En general, el presente estudio mostró que el uso de radiografías endodónticas tiene una cantidad significativa de información que puede usarse para identificar un cadáver. Por lo tanto, es importante realizar y almacenar radiografías de manera adecuada y durante períodos prolongados. La literatura relacionada con el tema es aún escasa y se necesitan más estudios.

Palabras clave: Odontología forense; Endodoncia; Radiografía dental; Antropología Forense.

\section{Introduction}

Forensic dentistry is a specialty that provides legal information by collecting, testing, and evaluating dental evidence, which can contribute to clarify several legal aspects, and identify the remains of individuals that cannot be visually recognized, i.e. in situations where the corpse is already in an advanced stage of decomposition, skeletonized, or carbonized (Avon, 2004; Silva et al., 2006; Almeida et al., 2015). According to the Disaster Victim Identification Guide of Interpol, dental identification is considered the primary method of identifying cadavers. Its positive result is sufficient for personal identification without additional support from other methods (INTERPOL, 2018).

Endodontics is the specialty of dentistry that studies the morphology, physiology, and pathology of the dental pulp and periradicular tissues, to preserve the tooth through prevention, diagnosis, prognosis, treatment, and control of pulp and tooth changes. (Kerekes \& Tronstad, 1979; Bergenholtz, 2016). Conventional two-dimensional radiography is the most used imaging method in dentistry, with periapical radiographs having a fundamental role in endodontics, requiring several radiographic shots, both at the beginning, during, and after the endodontic intervention (Ee et al., 2014; Antony et al., 2020).

Dental structures are considered the most resistant in the human body. They are usually preserved after death, even when caused by fire or water, which makes them useful in cases of identification of victims with compromised human skeletal remains (Silveira, 2013). In addition, studies show that the materials used in dental restorations and endodontic treatments are highly durable and resistant, remaining in the dental cavity even when exposed to high temperatures, being of great importance in the identification process (Weisman, 1996; Spadácio et al., 2011).

The identification of human remains through dental documentation is performed through a comparative technique, whose objective is to compare dental records and information recorded by dentists in clinical consultations performed before the death of an individual. These data include written notes, studies, radiographs, and photographs, with post-mortem (after death) dental records obtained via forensic examination. Generally, people who have undergone dental care are easier to identify than those with little or no restorative materials in the dental arcade (Pretty, 2007; Almeida et al., 2015).

Radiographs are the most reliable source of antemortem data for identifying bodies as they record morphological details; are not prone to potential errors inherent in a purely written document; and can be precisely duplicated by a different operator on the same patient, allowing comparison with post-mortem findings (Forrest \& Wu, 2010). 
For forensic identification, it is necessary to have the medical records of the victims in hand so that the radiographs can be compared. In some countries, it is mandatory to read and update the medical records in a legible and up-to-date manner, and it is an ethical infraction to deny the patient or a medical expert access to the medical records (Conselho Federal de Odontologia, 2012). Detailed and accurate records are a vital part of the dental practice, allowing quality care and monitoring to patients, in addition to having an important role in teaching and research, as well as in legal matters (Charangowda, 2010).

Hence, the objective of this literature review is to evaluate the importance of endodontic radiographs in the identification of cadavers.

\section{Methodology}

An electronic search was performed on "PubMed", "Scielo", "Periódicos Capes" and "Web of Science" databases. The last access was carried out in February 2021 using combinations of the following keywords: forensic dentistry, forensic anthropology, endodontics, dental radiography. In addition, the bibliographies of all relevant articles were manually searched. A total of 24 publications were found. The inclusion criteria were full available articles that addressed the theme of the study. There was no restriction on language or type of study. At first, the works were selected according to their titles and then the abstracts were analyzed. Articles that did not have abstracts or did not address the proposed topic were excluded. Thus, 8 articles were selected.

\section{Results}

Table 1 provides a summary of the relevant findings from each selected study. The first clinical case report of victim identification using dental data was made by Weisman in 1996, whose radiographs of the remains found were compared to those obtained during endodontic treatment of the victim performed four years before the fire (Weisman, 1996). Other clinical cases of identification of cadavers through comparisons of antemortem and post-mortem endodontic radiographs were reported (Forrest \& Wu, 2010; Silva et al., 2014; Silva et al., 2016). In vitro studies have evaluated the resistance of root canal filling materials after high-temperature incineration, to assess their use in forensic identification (Savio et al., 2006; Bonavilla et al., 2008). In addition, a clinical study was found that investigated the discriminatory potential of the radiographic morphology of filled canals in forensic identification (Khalid et al., 2016). Finally, a literature review on the relationship between endodontics and cadaver identification was found (Ahmed, 2017).

Table 1. Description of selected studies.

\begin{tabular}{l|l|l|l|l|l|l}
\hline Author & \multicolumn{1}{|c|}{$\begin{array}{c}\text { Place of } \\
\text { Publication }\end{array}$} & Year & \multicolumn{1}{|c|}{ Title } & \multicolumn{1}{c}{$\begin{array}{c}\text { Type of } \\
\text { article }\end{array}$} & \multicolumn{1}{c}{ Objective } & Conclusion \\
\hline Weisman & $\begin{array}{l}\text { Aus. Endod. } \\
\text { Newsl }\end{array}$ & 1996 & $\begin{array}{l}\text { A key to } \\
\text { identification in } \\
\text { forensic dentistry: } \\
\text { Report of a case. }\end{array}$ & $\begin{array}{l}\text { Case report } \\
\text { A detailed } \\
\text { description of a } \\
\text { clinical case }\end{array}$ & $\begin{array}{l}\text { A burned person was } \\
\text { identified through upper } \\
\text { lateral incisor radiography } \\
\text { that was equivalent to the } \\
\text { dental records found, due to } \\
\text { previous endodontic } \\
\text { treatment. }\end{array}$ \\
\hline Silva et al. & $\begin{array}{l}\text { Acta Stomatol } \\
\text { Croat }\end{array}$ & 2014 & $\begin{array}{l}\text { Dental identification } \\
\text { through endodontic } \\
\text { radiographic records: } \\
\text { A case report }\end{array}$ & Case report & $\begin{array}{l}\text { Report a clinical } \\
\text { case of successful } \\
\text { human } \\
\text { identification }\end{array}$ & $\begin{array}{l}\text { Dental radiographs play a } \\
\text { valuable role as a legal tool, } \\
\text { and in endodontics, periapical } \\
\text { radiographs are essential for } \\
\text { good treatment making them a } \\
\text { solid source of antemortem } \\
\text { data. }\end{array}$ \\
\hline
\end{tabular}




\begin{tabular}{|c|c|c|c|c|c|c|}
\hline Silva et al. & $\begin{array}{l}\text { Journal of } \\
\text { forensic dental } \\
\text { sciences }\end{array}$ & 2016 & $\begin{array}{l}\text { Identifying murder } \\
\text { victims with } \\
\text { endodontic } \\
\text { radiographs }\end{array}$ & Case report & $\begin{array}{l}\text { A detailed } \\
\text { description of a } \\
\text { clinical case }\end{array}$ & $\begin{array}{l}\text { There is a growing trend in } \\
\text { human identification based on } \\
\text { endodontic evidence and } \\
\text { justice is aware of its } \\
\text { usefulness, so it is important } \\
\text { to raise awareness of how to } \\
\text { properly perform radiographic } \\
\text { techniques and register and } \\
\text { store them correctly. }\end{array}$ \\
\hline $\begin{array}{l}\text { Forrest et } \\
\text { al. }\end{array}$ & Aust Endod J & 2010 & $\begin{array}{l}\text { Endodontic imaging } \\
\text { as an aid to forensic } \\
\text { personal } \\
\text { identification }\end{array}$ & Case report & $\begin{array}{l}\text { A detailed } \\
\text { description of a } \\
\text { clinical case }\end{array}$ & $\begin{array}{l}\text { It was concluded that root } \\
\text { canal treatments provide } \\
\text { many morphological details } \\
\text { and their radiographs are } \\
\text { valuable data for } \\
\text { identification, especially in } \\
\text { cases where there is little data } \\
\text { available. }\end{array}$ \\
\hline Savio et al. & Forensic Sci Int & 2006 & $\begin{array}{l}\text { Radiographic } \\
\text { Evaluation of Teeth } \\
\text { Subjected to High } \\
\text { Temperatures: } \\
\text { Experimental Study } \\
\text { to Aid Identification } \\
\text { Processes }\end{array}$ & $\begin{array}{l}\text { "In vitro" } \\
\text { study }\end{array}$ & $\begin{array}{l}\text { Evaluate the } \\
\text { radiographic } \\
\text { characteristics of } \\
\text { endodontically } \\
\text { treated teeth, } \\
\text { restored or not, } \\
\text { after exposure to } \\
\text { high temperatures }\end{array}$ & $\begin{array}{l}\text { The results of the } \\
\text { radiographic examination } \\
\text { showed that several } \\
\text { significant radiographic } \\
\text { details were retained. }\end{array}$ \\
\hline $\begin{array}{l}\text { Bonavilla et } \\
\text { al }\end{array}$ & J Forensic Sci & 2008 & $\begin{array}{l}\text { Identification of } \\
\text { Incinerated Root } \\
\text { Canal Filling } \\
\text { Materials After } \\
\text { Exposure to High } \\
\text { Heat Incineration }\end{array}$ & $\begin{array}{l}\text { "In vitro" } \\
\text { study }\end{array}$ & $\begin{array}{l}\text { Evaluate the } \\
\text { elemental } \\
\text { composition of } \\
\text { materials before } \\
\text { and after high- } \\
\text { temperature } \\
\text { incineration }\end{array}$ & $\begin{array}{l}\text { The authors present a } \\
\text { fingerprint of endodontic } \\
\text { filling materials that are able } \\
\text { to withstand high heat } \\
\text { incineration to be used as an } \\
\text { aid in post-mortem } \\
\text { identification. }\end{array}$ \\
\hline Khalid et al & $\begin{array}{l}\text { J Forensic } \\
\text { Odontostomatol }\end{array}$ & 2016 & $\begin{array}{l}\text { Discrimination } \\
\text { potential of root canal } \\
\text { treated tooth in } \\
\text { forensic dentistry }\end{array}$ & $\begin{array}{l}\text { Cross- } \\
\text { sectional } \\
\text { study }\end{array}$ & $\begin{array}{l}\text { Investigate the } \\
\text { discriminatory } \\
\text { potential for } \\
\text { identifying root } \\
\text { canal morphology } \\
\text { in radiographs }\end{array}$ & $\begin{array}{l}\text { The filled canals of } \\
\text { uniradicular teeth have been } \\
\text { shown to have highly specific } \\
\text { morphological characteristics } \\
\text { that could assist in } \\
\text { identification. }\end{array}$ \\
\hline Ahmed & $\begin{array}{l}\text { European Journal } \\
\text { of General } \\
\text { Dentistry }\end{array}$ & 2017 & $\begin{array}{l}\text { Endodontics and } \\
\text { Forensic Personal } \\
\text { Identification: An } \\
\text { update }\end{array}$ & $\begin{array}{l}\text { Literature } \\
\text { review }\end{array}$ & $\begin{array}{l}\text { Provide } \\
\text { information on } \\
\text { the relationship } \\
\text { with endodontics } \\
\text { and forensic } \\
\text { identification }\end{array}$ & $\begin{array}{l}\text { Adequate knowledge of root } \\
\text { variations is essential for } \\
\text { forensic identification and } \\
\text { endodontists should be aware } \\
\text { of their responsibilities to } \\
\text { assist in identification. }\end{array}$ \\
\hline
\end{tabular}

Fonte: Autores.

\section{Discussion}

The information obtained in this literature review shows that endodontic radiographs represent an important biometric method in the recognition of victims. Identification is usually performed by comparing antemortem and postmortem records (Charangowda, 2010). Information contained in radiographs is considered definitive evidence in legal or identification proceedings (Sholl \& Moody, 2001, Kavitha et al., 2009). Forensic dentists are often called upon to identify the remains of individuals who cannot be visually identified, which covers a large number of situations such as burnt, fully decomposed, or mutilated remains (Ahmed, 2017). 
Endodontics emerges as a potential source of antemortem data as radiology is widely used to record, evaluate and plan endodontic treatment, (Forrest \& Wu, 2010; Silva et al., 2016). Endodontic radiographs can be accurately duplicated by any operator at different locations and times in the same patient (Khalid et al., 2016). However, the position of the radiographic images represents a challenge in identification. It may be necessary to reproduce more than one position or even technical errors present in antemortem radiography so that the post mortem radiography has similar characteristics in the comparison (Forrest \& $\mathrm{Wu}, 2010)$.

Endodontically treated teeth contain a rich source of data that allow antemortem and postmortem comparisons due to the different possible morphologies of root canals, the strength of endodontic filling materials, and the low probability of retreatment compared to coronary restorations (Weisman, 1996; Forrest; \& Wu, 2010; Silva et al., 2014; Silva et al., 2016). Root canal filling materials remain preserved after high-temperature incineration, showing greater resistance compared to materials used in coronary restoration, such as composite resins or amalgam (Savio et al., 2006). In addition, the elementary composition of materials used in endodontic treatment (e.g. gutta-percha cones, endodontic sealers, and fractured files) remains original after being incinerated, contributing to the generation of a database to aid in forensic identification (Bonavilla et al., 2008).

The dental surgeon has an ethical and legal obligation to produce dental radiographs (conventional or digital) and store them properly, for legal purposes or forensic identification (Almeida et al., 2015; Savio et al., 2006). All information in the medical record must be clearly written, duly signed, and dated by the person responsible (Avon, 2004; Almeida et al., 2015). The time of keeping the dental record is a subject of extreme complexity. There is no defined minimum period for the mandatory maintenance of dental records. The Federal Council of Dentistry, through Opinion no. 125/92, states that the possession of the medical record belongs to the patient and its custody by the professional, and should be stored for at least ten years after the patient's last appearance (Conselho Federal de Odontologia, 2004). On the other hand, the Consumer Protection Code ensures that dental records must be considered durable, especially in cases of negligence hidden in the medical record. For these situations, article 27 presents the limitation period in five years of the intention to repair the damage caused, starting the counting of the term from the knowledge of the damage (Saraiva, 2011).

\section{Conclusion}

Overall, this review shows that endodontic radiographs have a significant amount of information that can help to identify a cadaver, which makes Endodontics an important specialty for Forensic Dentistry. Thus, radiographs must be taken properly and stored for a long period, due to their value in identifying individuals. Literature related to the subject is still scarce and further studies are needed.

\section{Acknowledgments}

This work was supported by the Brazilian agencies São Paulo State Research Foundation (FAPESP) [Grant numbers 2018/18741-0, 2019/14995-0], and CAPES (Finance code 001).

\section{References}

Ahmed, H. M. (2017). Endodontics and forensic personal identification: An update. European Journal of General Dentistry, 6(1),5-8. doi.org/ 10.4103/22789626.198593

Almeida, S. M., Delwing, F., Azevedo, J. A. P., Nogueira, R. K. T., Falcão, F. P., Carvalho, S. P. M. (2015). Effectiveness of dental records in human identification. South Brazilian Dental Journal, 63(4), 502-506. doi.org/10.1590/1981863720150003000213017 
Antony, D. P., Thomas, T., \& Nivedhitha, M. S. (2020). Two-dimensional Periapical, Panoramic Radiography Versus Three-dimensional Cone-beam Computed Tomography in the Detection of Periapical Lesion After Endodontic Treatment: A Systematic Review. Cureus, 12(4), e7736. doi.org/10.7759/cureus.7736

Avon S. L. (2004). Forensic odontology: the roles and responsibilities of the dentist. Journal Canadian Dental Association, 70(7), $453-458$.

Bergenholtz G. (2016). Assessment of treatment failure in endodontic therapy. Journal of oral rehabilitation, 43(10), 753-758. doi.org/10.1111/joor.12423

Bonavilla, J. D., Bush, M. A., Bush, P. J., \& Pantera, E. A. (2008). Identification of incinerated root canal filling materials after exposure to high heat incineration. Journal of forensic sciences, 53(2), 412-418. doi.org/10.1111/j.1556-4029.2007.00653.x

Charangowda, B. K. (2010). Dental Records: An Overview. Journal of Forensic Dental Sciences, 2(1),5-10. doi.org/10.4103/0974-2948.71050.

Conselho Federal de Odontologia. (2004). Prontuário odontológico: uma orientação para o cumprimento da exigência contida no inciso VIII do art. 5. ${ }^{\circ}$ do Código de Ética Odontológica.

Conselho Federal de Odontologia. (2012). Resolução CFO nº 118, 1 de Jan. 2013. Código de Ética Odontológico. Diário Oficial da União.

Ee, J., Fayad, M. I., \& Johnson, B. R. (2014). Comparison of endodontic diagnosis and treatment planning decisions using cone-beam volumetric tomography versus periapical radiography. Journal of endodontics, 40(7), 910-916. doi.org/10.1016/j.joen.2014.03.002

Forrest, A. S., \& Wu, H. Y. (2010). Endodontic imaging as an aid to forensic personal identification. Australian endodontic journal: the journal of the Australian Society of Endodontology Inc, 36(2), 87-94. doi.org/10.1111/j.1747-4477.2010.00242.x

INTERPOL. (2018). Disaster victim identification guide. Available from: https://www.interpol.int/en/content/download/589/file/18Y1344 E DVI_Guide.pdf.

Kavitha, B., Einstein, A., Sivapathasundharam, B., Saraswathi, T.R. (2009). Limitations in forensic Odontology. Journal of Forensic Dental Sciences, 1, 8-10. doi.org/10.4103/0974-2948.50881

Kerekes, K., Tronstad, L. (1979). Long-term results of endodontic treatment performed with a standardized technique. Journal of endodontics, 5(3), 83-90. https://doi.org/ 10.1016/S0099-2399(79)80154-5

Khalid, K., Yousif, S., \& Satti, A. (2016). Discrimination potential of root canal treated tooth in forensic dentistry. The Journal of forensic odontostomatology, 34(1), 19-26.

Pretty, I.A. (2007). Forensic dentistry: 1. Identification of human remains. Dental Update, 34(10, :621-634. doi.org/ 10.12968/denu.2007.34.10.621

Sholl, S. A., \& Moody, G. H. (2001). Evaluation of dental radiographic identification: an experimental study. Forensic science international, 115(3), 165-169. doi.org/10.1016/s0379-0738(00)00305-4

Saraiva, A.L.S. (2011). The importance of dental records - with emphasis on digital documents. Brazilian Journal of Dentistry, 68(2), 157-160.

Savio, C., Merlati, G., Danesino, P., Fassina, G., \& Menghini, P. (2006). Radiographic evaluation of teeth subjected to high temperatures: experimental study to aid identification processes. Forensic science international, 158(2-3), 108-116. doi.org/10.1016/j.forsciint.2005.05.003

Silva, R. F., Franco, A., Mendes, S. D., Picoli, F. F., Nunes, F. G., \& Estrela, C. (2016). Identifying murder victims with endodontic radiographs. Journal of forensic dental sciences, 8(3), 167-170. doi.org/10.4103/0975-1475.195112

Silva, R. F., Franco, A., Picoli, F. F., Nunes, F. G., \& Estrela, C. (2014). Dental Identification Through Endodontic Radiographic Records: a Case Report. Acta stomatologica Croatica, 48(2), 147-150.

Silva, R. F., Pereira, S. D. R., Mendes, S. D. S.C., Marinho, D. E. A., Daruge Junior, E. (2006). Dental radiographs: source of information for human identification. Odontologia clínico-científica, 5(3),239-242.

Silveira, E.M.S.Z.S.F. (2013). Dental importance within the Legal Medical Institute. Brazilian Journal of Occupational Medicine,11(1),34-39.

Spadácio, C., Oliveira, O. F., Benedicto, E. M., Daruge Júnior, E., Paranhos, L. R. (2011). Behavior analysis of esthetic restorations under the action of heat and its importance in the process of human identification. RFO UFP,16(3):267-272. doi.org/10.5335/rfo.v16i3.2276

Weisman, M. I. (1996). Endodontics - A key to identification in forensic dentistry: Report of a case. Australian Endodontic Journal, 22(3),9-12. doi.org/10.1111/j.1747-4477.1996.tb00548.x 